\title{
Fostering public accountability in South Africa: A reflection on challenges and successes
}

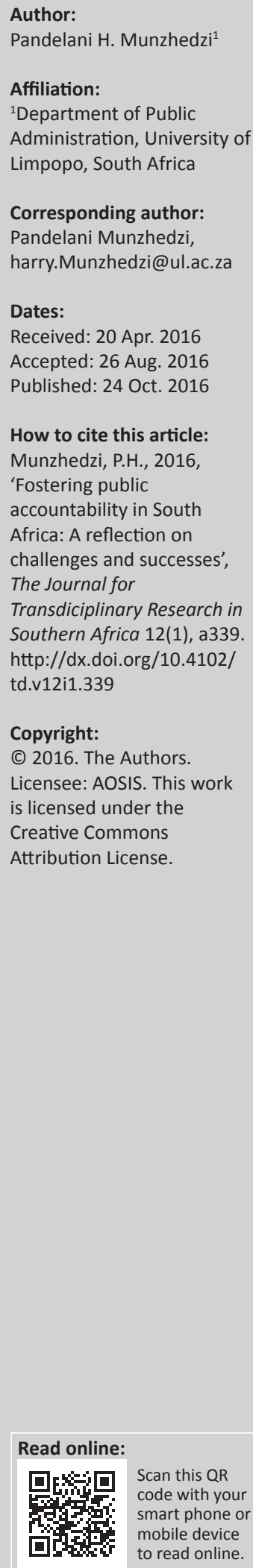

\begin{abstract}
Accountability and oversight are constitutional requirements in all the spheres of government in the Republic of South Africa and their foundation is in the Constitution of the Republic of South Africa of 1996. All spheres of government are charged with the constitutional mandate of providing public services. The level of responsibility and public services provision also goes with the level of capacity of a particular sphere. However, most of the direct and visible services that the public receives are at the local sphere of government. As such, enormous resources are channelled towards this sphere of government so that the said public services could be provided. It is imperative that the three spheres of government account for the huge expenditures during the public service provision processes. The parliaments of national and provincial governments exercise oversight and accountability over their executives and administrations through the Public Accounts Committees, while the local sphere of government relies on the Municipal Public Accounts Committees. This article is theoretical in nature, and it seeks to explore the current state of public accountability in South Africa and to evaluate possible measures so as to enhance public accountability. The article argues that the current public accountability mechanisms are not efficient and effective. It is recommended that these mechanisms ought to be enhanced by inter alia capacitating the legislative bodies at national, provincial and local spheres of the government.
\end{abstract}

\section{Introduction}

Steadily, the South African government has devoted much attention and its limited resources to the local sphere of government so as to perform its constitutional obligations. Mogale (2003:229) and Mfene (2013:17) posit that to capacitate municipalities to meet developmental requirements and speed up service delivery, extensive human and financial resources acquisition is necessary. Furthermore, the adoption of key and enabling legislative measures became essential to realise developmental local government objectives. Such legislative measures include the Local Government: Municipal Systems Act, 2000 (Act 32 of 2000), Local Government: Municipal Finance Management Act, 2003 (Act 56 of 2003) and Local Government: Municipal Property Rates Act, 2004 (Act 6 of 2004). There is an increasing pressure on public officials to demonstrate a high level of accountability concerning the utilisation of public resources (Van der Nest, Thornhill \& De Jager 2008:545). The accountability requirements and the necessity for sound financial management have brought public sector managers in close contact with accountability instruments including internal audit and the audit committee of particular institutions.

Accountability in South Africa has its origin in the Constitution of the Republic of South Africa, 1996. Cloete (1996:xi) and Mbatha (2002:1) are in agreement that accountable government in the public sector is an essential prerequisite for a democratic dispensation. They also emphasise that public sector institutions are universally faced with the issues of ethical and transparent administration and implementing good corporate governance. Public officials account to political executive office-bearers and political executive office-bearers account to parliament or municipal councils in the context of municipalities (Minnaar 2010:17). Parliament on the other hand is composed of elected office-bearers who account to the electorate. This theoretical article seeks to explore the current state of public accountability in South Africa and also evaluates its effectiveness and efficiency in the public sector. Possible improvement measures would be suggested including but not limited to enhancing accountability mechanisms of both administrative and political officials through performance management systems, punishing offenders who contravene legislative prescripts, and recruiting and retaining qualified and efficient administrative officials.

\section{Conceptualising public accountability}

Accountability refers to an obligation to expose, explain and justify actions (Van der Nest et al. 2008:546). It demands that the actions of public institutions be publicised to encourage public 
debate and criticism (Kuye \& Mafunisa 2003:425; Mafunisa 2003:18; Vyas-Doorgapersad \& Ababio 2006:393). On the other hand, Moeti (2014) is of the opinion that public accountability is 'an obligation to answer for the fulfilment of assigned and accepted duties within the framework of authority and resources provided'. Basically, accountability involves answering to a higher authority in the bureaucratic system of oversight (Kearns 1996:7). As posited by Van der Nest et al. (2008:545), financial accountability is not the only form of accountability, though it plays a substantial role in public accountability. However, the whole process of public accountability often has to do with issues concerning spending of public funds, exercise of public authorities, and the actual conduct of public institutions (Scott 2000:41). This is applicable in national and provincial government departments, district and local municipalities, parastatals and government entities. Van der Nest et al. (2008) are of the opinion that a synonym for accountability is answerability. Mfene (2013:7) also concurs that an organisation, or a government official, must be answerable to someone, or something, beyond itself. But of paramount importance is that accountability is not limited to public expenditure but includes reporting on the progress, performance, failures, successes, actual versus targeted performances, and on the general exercise of authority delegated by a superior authority (Ababio 2007:5; Munzhedzi 2014:703).

It therefore means that public accountability has to do with ensuring that those who are vested with public mandate to control and run public offices are required by law to answer and justify their actions and conducts through a forum that is pre-determined (Flinders 2001:19; Ijeoma \& Sambumbu 2013:284). Public accountability is often reciprocal in that it starts the moment one assumes powers or starts exercising vested authority to utilise public resources (Minnaar 2010:17; Mulgan 2003:1). The reason is that there ought to be checks and balances so that an abuse of power by authorities may be avoided or at least minimised. In this instance, there are two principal actors in the public accountability process; firstly, holders of public office and, secondly, the forum at which they report, which could either be the Public Accounts Committees, Municipal Public Accounts Committees, accounting officers or immediate supervisors. If certain legal or operational provisions have not been adhered to then these forums may recommend punitive measures which may include dismissal from work or instituting criminal proceedings against an affected employee (Raga \& Taylor 2006:16). It must also be noted that the entire process of accounting which includes all relevant meetings, dismissal process, and criminal proceedings must be done in a transparent manner. Transparency is very paramount in the process of ensuring public accountability. However, Pollitt $(2005: 207)$ is of the opinion that even though transparency is often regarded as a prerequisite for public accountability, transparency may not in any case be regarded as synonymous of it. In concurrence to Pollitt's view, this article believes that citizen participation and stakeholder's engagement are also essential elements of public accountability, but they may not in any way substitute it because they are analogous. Current mechanisms that are used to foster accountability in South Africa are appraised below so as to comprehend their effectiveness and efficiency and also recommend improvement mechanisms.

\section{Mechanisms of ensuring accountability}

The Constitution of the Republic of South Africa of 1996 (hereafter referred to as the 1996 Constitution) provides for various mechanisms of fostering public accountability. It is worth noting that some existing accountability mechanism sought to be evaluated so as to recommend effective and efficient approaches and enhance their functionalities. The said different mechanisms are discussed below.

\section{Parliament}

Members of both national and provincial parliament are elected by the electorate in South Africa and they are in turn accountable to the electorate for the powers bestowed unto them (Minnaar 2010:17). The National Assembly, which is the main house of parliament in South Africa, elects the President of the Republic in its first sitting who in turn nominates his national ministers and their deputies from the same house. However, the relationship of the President of the country and the parliament is complicated in that the he is the president of the majority party. According to the 1996 Constitution, the President and his cabinet account to parliament regularly in the execution of their responsibilities. Section 55 of the 1996 Constitution provides the following powers and functions to the National Assembly:

- Consider, pass, amend or reject any legislation.

- Initiate or prepare legislation, except money bills.

- Ensure that all executive organs of the state are accountable to it.

- Ensure that legislation is implemented appropriately.

- Maintain oversight on the conduct of the duty of the executive.

- Ensure that persons, institutions and all organs of the state comply with the 1996 Constitution (Nsingo 2014:46; Republic of South Africa [RSA] 1996).

The foregoing powers and functions also indicate that the National Assembly shall hold the executive which includes the president, deputy president, ministers and deputy ministers, accountable for all their actions including public expenditure. The executive shall also account for implementing laws passed by the parliament. Ultimately, the executive is to operationalise passed laws into measurable performance targets and actualise those targets so that the overall objectives of the passed laws are realised. However, Nsingo (2014:47) posits that more power lies with the electorate. The reason being that the electorate may withdraw their mandate from the political office-bearers through general election, because all political, economic and social decisions should be based on public interest. In the same token, public officials may be called to account by their superiors for not achieving the set objectives (Mfene 2013:18). It must be noted that parliament operates in a 
political environment which reflects the political system in that they are elected through a public vote and such a vote could be withdrawn at the next general election. Jacobs and Shapiro (2000:326) share this view and note that accountability requires that voters assign responsibility to those in power whom they consider to be responsible for faulty policy decisions. Some of the crucial decisions taken by parliament relate to collection of financial resources, allocation of resources through budget approval and accounting to the original authority (electorate) (Gildenhuys 1997:45). It can be deduced that accountability occurs when one is answerable and responsible for actions.

The current state of affairs in South Africa is indicative of a scenario where the answerability of the executive to parliament is proving to be a challenge. Opposition parties have consistently raised the issue that the majority party shields members of the executive in answering questions in parliament. They argue that it is for this reason that all budget votes that are presented by ministers end up being adopted and approved with only little critique from the opposition benches and no critique from the ruling party at all. In order to sustain the notion of democracy in South Africa, Mfene (2013:8) posits that those elected to such positions need to be accountable for the management of goods and services to improve the lives of people. However, Kuye and Mafunisa (2003:422) postulate that the allocation of responsibility in government has been complicated even further by the interposition of political appointees or temporary officials between political executives and permanent public servants.

The Standing Committee on Public Accounts (SCOPA) which focuses on public expenditure by the executive scrutinises the report of the Auditor-General regarding the financial management of various public institutions. SCOPA then summons whoever it deems necessary to appear before it and answer questions regarding the expenditure of public monies. Nsingo (2014:49) notes that most of the parliamentary work is done by committees of which SCOPA is one. SCOPA is different from other portfolio committees in that these committees cover a broad range of issues including considering bills, dealing with departmental budget votes, and overseeing the work of the department they are responsible for while SCOPA focuses on public expenditure by the executive. SCOPA may also summon administrative heads of departments as they play a pivotal role in these expenditures to account on the manner in which the public money was spent. This article argues that while a challenge may occur between the political executives and ordinary members of parliament, the same cannot be said about the accounting officers and different portfolio committees. The reason seems to be the fact that accounting officers do not enjoy the same powerful political status as ministers. As such, they do not receive the same 'shielding' by the ruling party as ministers who appear before the SCOPA and different portfolio committees.

\section{Public Protector}

As an accountability mechanism, the Public Protector has the power to investigate any conduct in state affairs, or in public administration in any sphere of government that is alleged or suspected to be improper or to result in any impropriety or prejudice. Chapter 10 of the 1996 Constitution states that the Public Protector shall, on his or her own initiative or on receipt of a complaint, investigate any alleged maladministration, abuse or unjustifiable exercise of power, improper or dishonest act, corruption, and unlawful enrichment. The Public Protector shall also investigate any receipt or any improper advantage, or promise of such enrichment or advantage, by a person as a result of an act or omission in the public administration of public institutions, or omission by a person in the employ of any sphere of the government, or a person performing a public function, which results in unlawful or improper prejudice to any person (Mafunisa 2003:15).

The legislative framework regulating the Office of the Public Protector in South Africa is the Public Protector Act, 1994 (Act 23 of 1994). The Office measures its effectiveness in respect of whether recommendations in a particular case are followed. It has been found that while the government does act in most cases, it does not always follow the recommendations, particularly with respect to politicians (Public Service Commission [PSC] 2001:20). The case in point is the remedial actions involving the building of the presidential residence in Nkandla. There have been enormous disagreements regarding the interpretation of the Public Protector's findings and remedial actions between political parties in parliament. Needless to say that 'small cases' are often implemented without much difficulty. Mafunisa (2003:15-17) is of the opinion that those who are found to be corrupt or involved in conflict of interest must be punished to make the recommendations of the Public Protector effective in curbing conflict of interest, and also to promote public confidence in the functioning of the Office. Not implementing the remedial actions of the Public Protector may effectively weaken the Office of the Public Protector.

\section{Auditor-General}

The Auditor-General is a Chapter 9 institution established by the 1996 Constitution as an oversight body responsible for overseeing the management of public finances on behalf of the parliament (Nsingo 2014:50). The functions of the Auditor-General are to ascertain, investigate and audit all the accounts and financial statements of:

- All departments of the national, provincial and local spheres of the government; and

- Any statutory body or any other institution which is financed wholly or partly by public funds, including public corporations and parastatals.

Besides conducting performance audits, once public expenditure of departments has been audited, the AuditorGeneral prepares and publishes a report for that particular 
public institution (Nsingo 2014:50). The report is then submitted to parliament for discussion. However, it may be safe to note that the authority of the Auditor-General ends with the submission of a report and recommendations to parliament. The Auditor-General is basically the extension of parliamentary committees including SCOPA in that they use the very report of the Auditor-General to summon whoever they wish to summon, particularly the accounting officers and political heads of departments. Each public sector institution receives its own audit outcome which is then consolidated into the main report either of all municipalities or of all national government departments. Du Toit (1991:67) notes that through his or her responsibility for performance auditing, the Auditor-General judges policies and transactions in terms of the 'value for money' principle. Accounting officers refer to the highest ranking administrative officials who head a state department or municipality or any other public sector institution inclusive of parastatals and public co-operations. They are also known as the chief executive officers (Mafunisa 2003:14). Although these administrative officials often work under the direct supervision of government ministers, they are directly accountable to parliament in respect of their performance, particularly financial matters. All legislatures have got public accounts or finance committees (SCOPA) which summon accounting officers to give an account of financial transactions involving their specific institutions.

Amongst others, Section 4(d) of the Auditor-General Act, 1995 (Act 12 of 1995) provides that the Auditor-General shall satisfy him/herself that:

- Reasonable precautions have been taken to safeguard proper collection of money, receipt, property, equipment, stores, trust money, trust property and other assets.

- Receipts, payments and other transactions are in accordance with the applicable laws and instructions; and

- Satisfactory control measures have been taken to ensure that resources are economically and utilised efficiently and effectively (Nsingo 2014:50).

It must however be noted that an important relationship exists between parliament and the Auditor-General in that the former approves the budget, while the later audits the expenditure of the approved budget. The Auditor-General actually compares actual expenditure with targeted expenditure of a financial year in all public institutions including government departments, municipalities, parastatals and public co-operations. According to the Auditor-General (2013:47), the lack of accountability and lack of consequences for poor performance and transgressions by the executive and administration are often the cause of poor audit outcome. This is in concurrence to Munzhedzi's (2013:282) view that inadequate financial skills, lack of commitment and inappropriate procurement practices are contributory factors to a poor state of financial affairs. Auditor-General also posits that most government departments and entities often have findings on non-compliance with laws and regulations and
$85 \%$ of these departments had one or more findings on transgression of supply chain management (SCM) regulations in the 2012 and 2013 financial year.

As long as there are no consequences for inappropriate behaviour, public institutions often continue to have findings on non-compliance with laws and regulations. This is evidenced by the poor audit outcomes and the fact that the total irregular expenditure incurred by the Limpopo Province in the 2012 and 2013 financial year remained stagnant. This poses a serious threat to the achievement of clean administration by the year 2014 and beyond (AuditorGeneral 2013:47). The Auditor-General further posits that key officials lacking appropriate competencies to be one of the root causes of poor audit outcomes which also makes it difficult for almost half of the departments and public entities to produce financial statements without any material misstatements. The audit had also identified this challenge as one of the root causes in 2011 and 20112, but there has been little or no improvement in this regard (Munzhedzi 2014:701). Auditor-General works with other stakeholders including parliament and different public institutions so as to assist in safeguarding public funds. The work of the Auditor-General may not be effective, if parliament is failing to hold accounting officers and political heads accountable. Furthermore, the public institutions ought to implement the advices and the recommendations advanced by the Auditor-General so as to address some of the challenges identified by the AuditorGeneral during the audit process.

\section{Public Service Commission}

The PSC main role as mandated by the 1996 Constitution is that of playing an oversight and monitoring role of the entire public service (Kuye \& Mafunisa 2003:434). It is responsible for investigating, monitoring and evaluating the organisation and practices of the South African public service. It derives its mandate from Sections 195 and 196 of the 1996 Constitution. Section 195 of the Constitution sets out the following values and principles of public administration that must be promoted by the PSC:

- Promoting and maintaining a high standard of professional ethics;

- Providing services impartially, fairly, equitably and without bias; and

- Ensuring accountability on the part of public administration (Mafunisa 2003:16; RSA 1996).

Corruption is one of the enormous challenges confronting all spheres of government (Balkaran 2013:129; PSC 2001:24), and the PSC has introduced financial disclosures by members of senior management services (SMS), otherwise known as senior managers. This is specifically done to address conflict of interest issues that often arise when the government senior managers (or any other government official) want to do business with the government. The challenge is that these managers are responsible for taking most government decisions including awarding of government business 
contracts which may not pass the basic principle of natural justice which requires that one cannot be a judge in his and/ or her own case. However, the compliance rate regarding these declarations has not been effective in curtailing corruption and enhancing accountability in that there's still a huge number of government employees' doing business with government without having declared (Kuye \& Mafunisa 2003:434). The PSC (2013:14) concurs that some of the mechanisms it employed to ensure accountability, professionalism, and impartiality have not been effective.

\section{National Prosecuting Authority}

Section 179 of the 1996 Constitution creates a single National Prosecution Authority (NPA). The 1996 Constitution, read with the National Prosecuting Authority Act, 1998 (Act 32 of 1998), grants the NPA the power to institute criminal proceedings on behalf of the State and to ensure that perpetrators of crime are charged and held responsible for their criminal actions. It must be noted that NPA as a huge and complex organisation consists of several business units including National Prosecutions Service (NPS), Asset Forfeiture Unit (AFU), Sexual Offences and Community Affairs (SOCA), Specialised Commercial Crime Unit (SCCU), Witness Protection Unit (WPU), and Priority Crimes Litigation Unit (Moeti 2014:123). The 1996 Constitution provides that the NPA should ensure justice for all victims of crime by prosecuting without fear, favour and prejudice. The National Director who is the overall administrative head of the prosecuting authority may intervene in any process of prosecution and review the decision to prosecute or not prosecute when the policy directives are not being complied with. This review may only be considered after careful consultation with the Director of Public Prosecutions, hearing representations from the accused, or any other relevant person that the National Director may deem appropriate.

Of ultimate importance with regard to the NPA is the fact that its independence should be preserved, and that it must implement the law and the Constitution and also perform its functions without fear, favour and prejudice (Republic of South Africa [RSA] 1998). However, the office of the NPA is often linked with controversies and cases of impartiality which often bring the credibility of the office into question. Moeti (2014:124) uses the example of the disbandment of the Scorpions which had a conviction rate of $80 \%$ in 2009 which was seen as a pursuance of political environment. It has since been replaced by the Directorate for Priority Crime Investigation (otherwise known as the Hawks) which has been put under the authority of the South African Police Service (SAPS). Very often, the NPA is associated with lack of independence against connected political elite. One of the most important business units in the NPA is the AFU which was also established in 1999 in the Office of the National Director of Public Prosecutions to focus on the implementation of Chapters 5 and 6 of the Prevention of Organised Crime Act, 1998 (Act 121 of 1998). The AFU's principal mandate is to seize criminal assets. However, this unit has not been without its own accusations of impartiality and infighting from within. Even though the NPA plays a significant role in the criminal justice system by ensuring that perpetrators of crime account for their criminal action, it has not necessarily been effective, particularly regarding its continued allegation of biasness, impartiality and independence.

\section{Special Investigating Unit}

The Special Investigating Unit (SIU) is a supposedly independent statutory body that is directly accountable to the parliament and the President of the Republic of South Africa. It was established by the President, to conduct investigations at his request and report to him on the outcomes. The request to conduct investigations by the President is done through the publication of a proclamation in the government gazette (Moeti 2014:122). It receives its budget through the Department of Justice and Correctional Services. The SIU has been created in terms of the SIUs and Special Tribunals Act, 1996 (Act 74 of 1996). The SIU was initially headed by former Judge Willem Heath who resigned in June 2001 after the Constitutional Court ruled that a judge could not head the SIU.

The primary mandate of the unit was to recover and prevent financial losses to the state caused by acts of corruption, fraud, maladministration, improper conduct by elected officials, unlawful expenditure of public funds, unapproved transaction, negligent loss of public money or damage to public property, and public sector corruption (Moeti 2014:122-123; RSA 1996). SIU works closely with the Hawks, SAPS as well as the NPA and AFU in the NPA to ensure that there is effective investigations and prosecutions of alleged corruption, fraud and maladministration. The AFU comes in handy where its powers and expertise are more appropriate or effective in recovering the proceeds of crime. The AFU applies a multidisciplinary approach to its investigations by combining both the expertise of forensic investigators, forensic lawyers, forensic accountants, cyber forensic specialists and data analysts supported by specific law enforcement powers as provided for by the SIUs and Special Tribunals Act, 1996 (Act 74 of 1996). All these SIU investigators may, with the authorisation of the magistrate or judge, enter and search premises and remove documentation on the basis of reasonable suspicion that would assist the investigation (Moeti 2014:123). The role performed by the SIU is very significant in that its functions cannot be performed by any other constitutional body.

\section{Judicial institutions}

The existence and proper functioning of judicial institutions including the courts of law are further deterrents against unethical behaviour in the public sector. Rasheed and Olowu (1993) argue that the judiciary contributes to scrutinising the abuse of administrative power and making political officebearers and public officials account for their actions. Legal disciplinary sanctions are instituted against the erring political office-bearers and public officials. Maluleke (in Mafunisa 2000:64) is of the opinion that imprisonment 
without the option of a fine should be the minimum sentence for those involved in corruption. Even though Maluleke's assertion may assist, it may not necessarily be the only penalty. Court cases often receive wide publicity in the press if it has to do with misappropriation of government resources and lack of accountability. To this end, the fear of being exposed in public by the press in itself is a factor which might discourage political office-bearers and public officials from acting in an irresponsible and unethical manner. Cloete (1993:124-125) posits that for the courts of law to be effective in instilling a sense of accountability to political office-bearers and public officials, the independence and objectivity of these courts of law must be maintained. It must be argued that the South African courts have really played a pivotal role in ensuring accountability in the public sector. However, courts have got their own weaknesses with regard to issues of accessibility in that they are expensive (O'Regan 2005:128; Venter \& Landsberg 2011:70). Furthermore, those who are accused of maladministration, fraud and corruption at times defend themselves at state expense. In other words, state often has to foot the bill for some of these cases. Examples of such cases are former police commissioner Jackie Selebi's corruption case and President Jacob Zuma's corruption case regarding the arms deal.

\section{Reflection on current state of accountability in South Africa}

While the involvement of political executives (president, ministers, premiers, members of executive councils (MECs), councillors and mayors) in unlawful or questionable activities has drawn much public attention to the issue of political responsibility, the status of administrative responsibility has also become a matter of increasing anxiety (Kuye \& Mafunisa 2003:422). While elected officials make the final decisions on major public policy issues, public servants have significant influence on these decisions and also have authority to make decisions on their own that affect the individual and collective rights of the citizenry. The 1996 Constitution clearly provides that 'members of the Cabinet (president, deputy and ministers) are accountable collectively and individually to parliament for the exercise of their powers and the performance of their functions' (Minnaar 2010:17; RSA 1996). However, in practice this has proved to be a difficult phenomenon in that some ministers delay their appearance (if they appear at all) in the respective portfolio committees of parliament. In other instances, ministers send their deputies to 'account on their behalf' either in the National Assembly or Portfolio Committees.

The mechanisms discussed above as a means of ensuring public accountability in South Africa have to an extent had a good impact, but a big hole still exists. A very good policy framework including the 1996 Constitution, Public Finance Management Act, 1999 (Act 1 of 1999), and the Local Government: Municipal Finance Management Act, 2003 (Act 56 of 2003) exists. The challenge is the practice of what is in the legislations. Even when the provision of legislation is very clear, the implementation seems to be difficult. Lately, the powers of the Public Protector as an accountability mechanism have been in question, particularly the enforcement of the remedial actions. The Auditor-General has also played a pivotal and effective role in producing audit outcomes for public institutions, and parliament often relies on those findings to hold the executive to account. However, the effectiveness of the Auditor-General does not necessarily mean that parliament will use such reports efficiently if at all. The NPA has been established to prosecute those who have committed crime like fraud and corruption; however, its success rate could be improved. Several political and public-office bearers have contravened the provisions of the legal prescripts like the Public Finance Management Act, 1999 (Act 1 of 1999), but they are yet to be punished years after such actions (Munzhedzi 2013:283). It is concluded that there is lack of commitment to punish those who are wrong.

\section{Conclusion and recommendations}

South Africa is still confronted with many challenges in so far as lack of accountability is concerned. The unfortunate part is that there are no ready-made solutions to these challenges. However, some of the measures which could be applied to address the said challenges include the following:

- Accounting officers together with all administrative staff must be held accountable through an effective employee performance management system where performance agreements stipulating clear performance targets are signed. In essence, regular monitoring of individual as well as organisational performance is necessary.

- The political leadership ought to augment their oversight responsibilities though forums such as Public Accounts Committees and Municipal Public Accounts Committees at the local sphere of government ensure that action is taken against transgressors. The skills of these oversight committees also need to be enhanced by nominating parliamentarians with capacity to hold the executive accountable.

- Internal control measures ought to be improved to ensure that weaknesses associated with internal controls are corrected. Regular monitoring of the implementation of internal control measures is necessary so that weaknesses are identified and addressed timeously.

- The authority vested with governance and oversight in government should ensure that accountability is enforced and appropriate consequences are implemented when officials do not comply with the requirements of an applicable legislative framework including Local Government: Municipal Systems Act, 2000 (Act 32 of 2000), Local Government: Municipal Finance Management Act, 2003 (Act 56 of 2003) and Preferential Procurement Policy Framework Act, 2000 (Act 5 of 2000).

- The Minister and MECs responsible for national and provincial treasury, respectively, should develop and implement initiatives to enhance the skills of officials by introducing continuous development programmes. This enhancement of skills should be inclusive of those of procurement officials, bid committee members, service 
providers as well as internal directors and managers of other business units.

- Government institutions through their accounting officers should implement effective and efficient recruitment measures to attract and retain skilled officials who will implement adequate accountability measures. Rewards and remuneration must also be linked to performance of individuals.

- Office of the Public Protector as an accountability mechanisms ought to be enhanced. Government institutions also need to develop respect for the Office of the Public Protector and implement its remedial actions or challenge the remedial action in the court of law.

The preceding measures of addressing public accountability challenges are vital so as to curtail or reduce the extent of corruption, lack of accountability and improve commitment to improve the state of financial affairs in South Africa. Munzhedzi (2013:282) is of the opinion that lack of commitment and a disregard for financial management and SCM legislative framework are major contributors to the poor state of public accountability. To this end, this article notes that most of the challenges associated with public accountability do not come about as a result of lack of appropriate policy frameworks, but because of the lack of appropriate implementation of existing policies fostering public accountability.

\section{Competing interests}

The author declares that he has no financial or personal relationship(s) which may have inappropriately influenced him in writing this article.

\section{References}

Ababio, E., 2007, 'Bloodhounds on municipal financial management: What goes awry?', Journal of Public Administration 42(5), 3-14.

Auditor General, 2013, Limpopo's general report on the audit outcomes of provincial government, Auditor-General of South Africa, Pretoria.

Balkaran, S., 2013, 'A captured mind is a captured state: The South African public service', in International Conference on Development Finance and Transformation's Conference Proceedings, Polokwane, 27-29 October, pp. 129-145.

Cloete, J.J.N., 1993, Democracy: Prospects for South Africa, Van Schaik, Pretoria.

Cloete, J.J.N., 1996, Accountable government and administration for the Republic of South Africa, Van Schaik, Pretoria.

Du Toit, A., 1991, Towards democracy: Building a culture of accountability in South Africa, IDASA, Pretoria.

Flinders, M., 2001, The politics of accountability and the modern state, Ashgate, London.

Gildenhuys, J.S.H., 1997, Introduction to the management of public finance: A South African perspective, Van Schaik Publishers, Pretoria.

Ijeoma, E.O.C. \& Sambumbu, A.M., 2013, 'A framework for improving public accountability in South Africa', Journal of Public Administration 48(2), 282-298.
Jacobs, L.R. \& Shapiro, R., 2000, Politicians don't pander: Political manipulation and the loss of democratic responsiveness, University of Chicago Press, Chicago, IL.

Kearns, K.P., 1996, Managing for accountability: Preserving the public trust in public and non-profit organisations, Jossey Publishers, San Francisco, CA.

Kuye, K.O. \& Mafunisa, M.J., 2003, 'Responsibility, accountability and ethics: The case for public service leadership', Journal of Public Administration 38(4), 421-437.

Mafunisa, M.J., 2003, 'Conflict of interest: Ethical dilemma in politics and administration', South African Journal of Labour Relations 27(2), 4-22.

Mafunisa, M.J. (ed.), 2000, Public service ethics, Juta, Kenwyn.

Mbatha, J.S., 2002, 'The ethical dimension of transparency in the public sector', Unpublished MAdmin thesis, University of South Africa, Pretoria.

Mfene, P.N., 2013, 'Public accountability: A professional basis for the South African public service', Administratio Publica 21(1), 6-23.

Minnaar, F., 2010, Strategic and performance management in the public sector, Van Schaik Publishers, Pretoria.

Moeti, K.B. (ed.), 2014, Public finance fundamentals, 2nd edn., Juta, Cape Town.

Mogale, T.M., 2003, 'Developmental local government and decentralised service delivery in the democratic South Africa', in G. Mhone \& O. Edigheji (eds.), Governance in the new South Africa, pp. 215-243, UCT Press, Lansdowne.

Mulgan, R., 2003, Holding power to account, Palgrave, New York.

Munzhedzi, P.H., 2013, 'Financial viability of the South African municipalities: Some observations on legal compliance', in International Conference on Development Finance and Transformation's Conference Proceedings, Polokwane, 27-29 Finance and Transform
October, pp. 281-292.

Munzhedzi, P.H., 2014, 'The national government's intervention in the provincial government: A case of Limpopo', Mediterranean Journal of Social Sciences 5(20), 699-704.

Nsingo, S., 2014, 'Role players in public financial management', in K.B. Moeti (ed.), Public finance fundamentals, pp. 44-57, Juta, Pretoria.

O'Regan, K., 2005, 'Checks and balances reflection on the development of the doctrine of separation of powers under the South African Constitution', PER 8(1), 120-150.

Pollitt, M., 2005, 'Learning from UK Private Finance Initiative experience', in G. Hodge \& C. Greve (eds.), The challenge of public-private partnerships: Learning from international experience, pp. 207-230. Edward Elgar Publishing Limited, Cheltenham, UK.

Public Service Commission (PSC), 2001, A review of South Africa's national anticorruption agencies, PSC, Pretoria.

Public Service Commission (PSC), 2013, Public Service Commission annual report 2012/13, PSC, Pretoria.

Raga, K. \& Taylor, D., 2006, Impact of accountability and ethics on public service delivery: A South African perspective, Nelson Mandela Metropolitan University, Port Elizabeth, South Africa.

Rasheed, S. \& Olowu, D. (eds.), 1993, Ethics and accountability in African public services, AAPAM, Addis Ababa.

Republic of South Africa (RSA), 1994, Public Protector Act, 1994 (Act 23 of 1994), Government Printers, Pretoria.

Republic of South Africa (RSA), 1995, Auditor General Act, 1995 (Act 12 of 1995), Government Printers, Pretoria.

Republic of South Africa (RSA), 1996, Constitution of the Republic of South Africa, 1996, Government Printers, Pretoria.

Republic of South Africa (RSA), 1998, National Prosecuting Authority Act, 1998 (Act 32 of 1998), Government Printers, Pretoria.

Scott, C., 2000, 'Accountability in the regulatory state', Journal of Law and Society 27 38-60. http://dx.doi.org/10.1111/1467-6478.00146

Van Der Nest, D.P., Thornhill, C. \& De Jager, J., 2008, 'Audit committees and accountability in the South African public sector', Journal of Public Administration 43(4), 545-557.

Venter, A. \& Landsberg, C., 2011, Government and politics in South Africa, Van Schaik, Pretoria.

Vyas-Doorgapersad, S. \& Ababio, E.P., 2006, 'Ethical dilemmas and democratic values: How to reposition institutions for good governance and increased service delivery', Journal of Public Administration 31(2.2), 385-396. 